\title{
On the origin and the laws of atmospheric electricity
}

\section{Prof. Franz Exner}

To cite this article: Prof. Franz Exner (1886) On the origin and the laws of atmospheric electricity, Philosophical Magazine Series 5, 21:133, 520-520, DOI: $10.1080 / 14786448608627890$

To link to this article: http://dx.doi.org/10.1080/14786448608627890

册 Published online: 29 Apr 2009.

Submit your article to this journal $₫$

Џ Article views: 3

Q View related articles $₫$ 
The strongest currents were shown by zinc, and the feeblest by copper.

The currents are, however, difficult to observe, doubtless owing to the facility with which they unite across the plates themselves; more powerful effects may be obtained by cutting a knee-piece in the metal plate, in one branch of which the long grain is across and in the other in the direction of the length, and then joining the two ends of the knee-piece to the external circuit.-Journal de Physique, April 1886.

\section{ON THE ORIGIN AND THE LAWS OF ATMOSPHERIC ELECTRICI'Y.} BY PROF. FRANZ EXNER.

After a critical historical discussion of previous theories, the author communicates the results of his experiments on this subject, which have extended over several years. They refer chiefly to an examination of the electrical field of the earth under normal atmospheric conditions. It has appeared that the equipotential surfaces are continually as if the Earth had a negative charge. Over a plane the fall of potential is always linear, and its absolute value is constant if the condition of the atmosphere does not change. Such changes are due to the greater or less quantity of aqueous vapour in the air, for this leaves the Earth charged with negative electricity.

The greatest fall of potential amounts to 600 volts per metre in the complete absence of aqueous vapour, and sinks to below 100 volts in the height of summer. These numbers hold, however, only for continuous fine weather. A measurement of the fall of potential in summer at great heights, by means of air-balloons, has proved that this increases considerably with the height; that is, that aqueous vapour in air is really negative.

All the phenomena of negative electricity are completely explained on the assumption already made by Peltier that the Earth contains a negative charge. Starting from Franklin's theory, this charge appears as a necessary consequence of the gradual formation of the Earth, and would correspond to an excess of electricity above the normal amount. Bodies which are in the condition last named would thus appear negatively electrified. From the magnitude of the fall of potential at the surface of the Earth, the absolute potential of the Earth may be determined. This is found to be $=-4 \cdot 10^{9}$ volt; that is to say, a point in space which is infinitely distant from all electrical masses has a potential which is $4 \cdot 10^{9}$ volts higher than that of the Earth. The repulsive force which is exerted by the charge of the Earth on a square centimetre of surface is equal to $16^{\cdot 10^{-9}}$ grams, and is thus extremely small. - Sitzungsberichte der kaiserlichen Akademie der Wissenschaften in Wien, February 1886. 